\title{
APPLYING INPUT-OUTPUT MODEL TO INVESTIGATE THE INTER- INDUSTRIAL LINKAGE OF TRANSPORTATION INDUSTRY IN TAIWAN
}

\section{Rong-Her Chiu}

Department of Shipping and Transportation Management, National Taiwan Ocean University, Keelung, Taiwan, R.O.C., chiu12@mail.ntou.edu.tw

Yu-Chang Lin

YES LOGISTICS CORP., Taipei City, Taiwan, R.O.C.

Follow this and additional works at: https://jmstt.ntou.edu.tw/journal

Part of the Management Information Systems Commons

\section{Recommended Citation}

Chiu, Rong-Her and Lin, Yu-Chang (2012) "APPLYING INPUT-OUTPUT MODEL TO INVESTIGATE THE INTERINDUSTRIAL LINKAGE OF TRANSPORTATION INDUSTRY IN TAIWAN," Journal of Marine Science and Technology. Vol. 20: Iss. 2, Article 8. DOI: $10.51400 / 2709-6998.1836$

Available at: https://jmstt.ntou.edu.tw/journal/vol20/iss2/8

This Research Article is brought to you for free and open access by Journal of Marine Science and Technology. It has been accepted for inclusion in Journal of Marine Science and Technology by an authorized editor of Journal of Marine Science and Technology. 


\title{
APPLYING INPUT-OUTPUT MODEL TO INVESTIGATE THE INTER-INDUSTRIAL LINKAGE OF TRANSPORTATION INDUSTRY IN TAIWAN
}

\author{
Rong-Her Chiu ${ }^{1}$ and Yu-Chang Lin $^{2}$
}

Key words: input-output analysis, transportation sector, Taiwan, inter-industrial linkage, production-inducing effect.

\begin{abstract}
This paper aims to investigate the role and influence of the transportation sector on the national economy of Taiwan by using input-output analysis. Data from the period 1991-2006 is used to analyze the inter-industrial linkage effects in 33 sectors. The results show that the transportation industry in Taiwan has more strength in absorbing the products of related industries rather than being used as an input by other industries; it has a relatively strong capacity for pulling in other industries Road transportation also has comparatively more strength in supporting other industries domestically. Taking the transportation industry as exogenous, this study further explores its economic effects on other sectors, including productioninducing, supply-shortage, and price effects.
\end{abstract}

\section{INTRODUCTION}

Transportation is vital to the movement of both freight and passengers around the world; it is also an important industry to a national economy [6]. Situated in the western Pacific rim, Taiwan is a small island with a land area of 36,000 square meters and a population of approximately 23 million in 2009 . Expenditures in transportation, storage, and communication comprise about $6.1 \%$ of the total gross domestic product during the 1991-2006 period [8]. Road and rail transport are responsible for providing domestic freight and passenger services, while water and air transportation mainly support the movements of international trade and travel of passengers. As a small island, Taiwan urgently needs well-developed sea and air transportation systems to transfer import and export products to and from foreign countries. Undoubtedly, it must also develop sufficient road and rail systems to support do-

Paper submitted 03/01/10; revised 06/28/10; accepted 11/11/10. Author for correspondence: Rong-Her Chiu (e-mail: chiu12@mail.ntou.edu.tw).

${ }^{I}$ Department of Shipping and Transportation Management, National Taiwan Ocean University, Keelung, Taiwan, R.O.C.

${ }^{2}$ YES LOGISTICS CORP., Taipei City, Taiwan, R.O.C. mestic transportation demands and economic development [19]. These needs motivate researchers to provide policymakers with accessible and reliable information on the role of the transportation industry. More importantly, a comprehensive description of the transportation industry and analysis of long historical series data are necessary to guide policymakers if the transportation sector is to become a major source of impetus for future economic growth.

As shown in Table 1, the ratio of total input and output of the transportation industry in Taiwan's economy is very low. It was only between $1.68 \%$ and $2.11 \%$ for input and $2.15 \%$ and $3.37 \%$ for output during the period of 1991-2006. Over the past 15 years, although the total output of the transportation sector doubly increased from NTD411,743 million in 1991 to NTD961,115 million in 2006, the ratio in the national economy also slightly increased from $2.33 \%$ to $3.37 \%$; however, the ratio of the transport sector's input decreased. The government in Taiwan may need to put more investment in the transportation sector, particularly in infrastructure.

When it comes to the contribution of the transport industry to the national economy, road transport ranked first, followed by the water and then the air transport sectors (Table 2). Rail transport maintained the smallest scale of output (approximately $3 \%$ ) compared with the other three major transportation modes. The current status of rail transport is reasonable because (1) Taiwan is only a small island and cannot provide many opportunities for rail transport particularly for distance cargo movement, and (2) rail transport cannot provide services for the conveyance of international trading cargoes. The road transportation sector contributed to over one-third of the transportation sector's output between 1991 and 2006, while water and air modes accounted for around one-fifth of the sector's output. The ratio of the road transportation sector's contribution (vis-à-vis total output) gradually decreased from $45.6 \%$ in 1991 to $30.8 \%$ in 2006 . Meanwhile, the air transportation sector continued to gain importance in the national economy, as its ratio of contribution increased from $12.4 \%$ to $25.4 \%$ during the same period. This indicates that the industrial structure is changing, and more international trading of goods and traveling of passengers require more air transportation services. 
Table 1. Ratio of the transportation sector in the total industry's input and output.

\begin{tabular}{l|c|c|c|c|c}
\hline & \multicolumn{3}{c}{ Unit: million NT dollars } \\
\hline \multirow{2}{*}{ Transport sector's input } & 1991 & 1996 & 2001 & 2004 & 2006 \\
\hline Total industry's input & 358,023 & 580,249 & 649,481 & 701,959 & 552,536 \\
$(1.03 \%)$ & $(2.11 \%)$ & $(1.92 \%)$ & $3.68 \%)$ & $(1.93 \%)$ \\
\hline \multirow{2}{*}{ Transport sector's output } & $41,664,677$ & $27,517,674$ & $33,911,381$ & $41,736,949$ & $28,554,915$ \\
\hline Total industry's output & $(2.33 \%)$ & $(2.47 \%)$ & $(2.29 \%)$ & $(2.15 \%)$ & $(3.37 \%)$ \\
\hline
\end{tabular}

Sources: Input-Output tables for 1991, 1996, 2001, 2004 and 2006 (provided by Directorate-General of Budget, Accounting and Statistics, Executive Yuan, Taiwan).

Table 2. Ratio of the individual transportation industry's output.

\begin{tabular}{c|c|c|c|c|c|c|c}
\hline \multicolumn{1}{c|}{} & \multicolumn{2}{c}{ Unit: million NT dollars } \\
\hline \multirow{2}{*}{1991} & Railway & Road & Water & Air & Warehouse & Other Transport & Total \\
\cline { 2 - 8 } & 13,396 & 188,100 & 84,813 & 51,161 & 15,226 & 59,047 & 411,743 \\
\hline \multirow{2}{*}{1996} & $(3.25 \%)$ & $(45.68 \%)$ & $(20.60 \%)$ & $(12.43 \%)$ & $(3.70 \%)$ & $(14.34 \%)$ & $(100 \%)$ \\
\cline { 2 - 8 } & 17,305 & 260,414 & 139,361 & 121,231 & 23,896 & 118,691 & 680,898 \\
\hline \multirow{2}{*}{2001} & $(2.54 \%)$ & $(38.25 \%)$ & $(20.47 \%)$ & $(17.81 \%)$ & $(3.51 \%)$ & $(17.43 \%)$ & $(100 \%)$ \\
\cline { 2 - 8 } & $(3.21 \%)$ & $(36.51 \%)$ & $(19.80 \%)$ & $(21.59 \%)$ & $(2.63 \%)$ & $(16.27 \%)$ & $(100 \%)$ \\
\hline \multirow{2}{*}{2004} & 24,419 & 294,466 & 192,632 & 219,400 & 23,113 & 144,698 & 898,728 \\
\cline { 2 - 8 } & $(3.21 \%)$ & $(36.51 \%)$ & $(19.80 \%)$ & $(21.59 \%)$ & $(2.63 \%)$ & $(16.27 \%)$ & $(100 \%)$ \\
\hline \multirow{2}{*}{2006} & 25066 & 295618 & 201754 & 244907 & 25004 & 168766 & 961,115 \\
\cline { 2 - 8 } & $(2.61 \%)$ & $(30.81 \%)$ & $(20.99 \%)$ & $(25.48 \%)$ & $(2.60 \%)$ & $(17.56 \%)$ & $(100 \%)$ \\
\hline \multirow{2}{*}{ Total } & 105,130 & $1,322,655$ & 772,578 & 804,703 & 107,727 & 617,754 & $3,730,547$ \\
\cline { 2 - 8 } & $(2.82 \%)$ & $(35.45 \%)$ & $(20.71 \%)$ & $(21.57 \%)$ & $(2.89 \%)$ & $(16.56 \%)$ & $(100 \%)$ \\
\hline
\end{tabular}

Sources: Input-Output tables for 1991, 1996, 2001, 2004 and 2006 (provided by Directorate-General of Budget, Accounting and Statistics, Executive Yuan, Taiwan).

This paper aims to investigate the role of the five transportation industries in the Taiwanese national economy for the period of 1991-2006 using a static input-output (I-O) approach to provide policymakers with at least a basic picture of the role of each transportation industry. The input-output (I-O) model was developed in the late 1930s by Wassily Leontief, a 1973 Nobel Laureate in Economics [15]. The fundamental purpose of the I-O framework is to analyze the interdependence of industries in an economy. Over the years, the I-O analysis has been extended to deal with various issues such as interregional flow of products and accounting for energy consumption, environmental pollution, and employment associated with industrial production $[3,18]$. Some researchers also applied the I-O model to analyze related transportation issues [13, 14, 27].

The remainder of this paper is organized as follows: Section 2 presents a brief literature review; Section 3 describes the I-O model employed by this study; Section 4 discusses the empirical results and provides the potential uses of these results in the transportation policy; and finally, Section 5 presents the concluding remarks.

\section{BRIEF REVIEW OF I-O ANALYSIS ON TRANSPORTATION INDUCTRY}

The I-O model could be a good research methodology to explore the influence of the maritime industry on the other sectors. However, there have been few studies that use the I-O model directly for analyzing the transportation industry. One of these rare studies was conducted by Kwak et al. [13] who employed comprehensive I-O models, including inter-industry linkage effect analysis, the demand-driven model, the supply-driven model, and the Leontief price model, to investigate the role of marine sector in the Korean national economy in 1975-1998. The study concluded that the maritime industry in Korea had low forward linkage, supply shortage cost, and price effects, while having high backward linkage, production-inducing, and employment-inducing effects. The current study only focuses on analyzing water transport; however it provides a good framework for expanding the domain to investigate the whole transportation industry (i.e., rail, road, air, water, and related auxiliary services). 
Table 3. Summary of literature review papers.

\begin{tabular}{|c|c|c|c|}
\hline Author & Topic & I-O model used & Empirical data \\
\hline $\begin{array}{l}\text { Kwak, S. J., Yoo, S. H., } \\
\text { and Chang, J. I. (2005) }\end{array}$ & $\begin{array}{l}\text { The role of the maritime industry in the } \\
\text { Korean national economy: } \\
\text { an input-output analysis }\end{array}$ & $\begin{array}{l}\text { 1. Basic I-O model. } \\
\text { 2. Forward \& backward linkage effects. } \\
\text { 3. Production-inducing effect. } \\
\text { 4. Supply-shortage effect. } \\
\text { 5. Price effect. }\end{array}$ & $\begin{array}{l}\text { I-O tables of } 1975,1980, \\
1985,1990\end{array}$ \\
\hline $\begin{array}{l}\text { Van Der Linden, Jan A. } \\
\text { (2001) }\end{array}$ & $\begin{array}{l}\text { The economic impact study of maritime } \\
\text { policy issues: application to the German } \\
\text { case }\end{array}$ & $\begin{array}{l}\text { 1. Concept of I-O analysis was used to } \\
\text { help performance assessment. } \\
\text { 2. No specific I-O model used. }\end{array}$ & Shipping output of 1997 \\
\hline $\begin{array}{l}\text { Bryan, Jane; Max Munday; } \\
\text { David Pickernell and } \\
\text { Annette Roberts (2006) }\end{array}$ & $\begin{array}{l}\text { Assessing the economic significance of } \\
\text { port activity: evidence from ABP } \\
\text { Operations in industrial South Wales }\end{array}$ & 1. Employment effects (multipliers). & 2003 collected data \\
\hline $\begin{array}{l}\text { Doll, Claus and Alex } \\
\text { Schaffer (2007) }\end{array}$ & $\begin{array}{l}\text { Economic impact of the introduction of } \\
\text { the German HGV toll system }\end{array}$ & $\begin{array}{l}\text { 1. Price effects. } \\
\text { 2. Employment effects. }\end{array}$ & 2002 data \\
\hline Ho, I-Shi (1986) & $\begin{array}{l}\text { Investigating the linkage between } \\
\text { transportation industry and } \\
\text { Macro-economic growth (in Taiwan) }\end{array}$ & $\begin{array}{l}\text { 1. Basic I-O model. } \\
\text { 2. Forward \& backward linkage effects. }\end{array}$ & I-O table of 1981 \\
\hline Lien, Yo-Wei (1986) & $\begin{array}{l}\text { A study on inter-industrial linkage of } \\
\text { transportation industry in Taiwan } \\
\text { (in Taiwan) }\end{array}$ & $\begin{array}{l}\text { 1. Basic I-O model. } \\
\text { 2. Forward \& backward linkage effects. } \\
\text { 3. Induced effects between transporta- } \\
\text { tion industry and the other industrial } \\
\text { sectors. }\end{array}$ & I-O tables of 1976, 1981 \\
\hline Wang, Tu-Fa (1990) & $\begin{array}{l}\text { Analyzing the economic effects of } \\
\text { transportation and communications } \\
\text { construction (in Taiwan) }\end{array}$ & $\begin{array}{l}\text { 1. Basic I-O model. } \\
\text { 2. Forward \& backward linkage effects. } \\
\text { 3. Income \& employment multipliers. }\end{array}$ & I-O table of 1984 \\
\hline $\begin{array}{l}\text { Nir, An-Shuen and } \\
\text { Gin-Shuh Liang (2003) }\end{array}$ & $\begin{array}{l}\text { Transport Sector Construction } \\
\text { Inter-industry Effects Positive Study } \\
\text { in Taiwan Area }\end{array}$ & $\begin{array}{l}\text { 1. Basic I-O model. } \\
\text { 2. Forward \& backward linkage effects. } \\
\text { 3. Output, income \& employment mul- } \\
\text { tipliers. }\end{array}$ & I-O table of 1996 \\
\hline
\end{tabular}

Van Der Linden [23] introduced the Policy ResearchEconomic Impact Study (EIS) to analyze the relationship between public policy and the economic performance of a sector, in order to draw up recommendations for continuing or changing the prevailing sector-oriented policy. The paper focused on the analysis of EIS and its applications to propose a new maritime policy for Germany. For the EIS, the I-O analysis was only employed to determine a sector's performance; the results of I-O analysis were then used as the prognoses for the various policy scenarios.

To argue for a better consideration of the role of ports in strategic economic development plans in Wales, Bryan et al. [1] employed the input-output framework to produce evidence that port infrastructure played an important role in supporting other Welsh businesses, requiring government authorities to more carefully consider the value of the port sector for the regional economic development. In stead of conducting a comprehensive analysis, the study only estimated the economic effects on employment, incomes and output supported by the ports.

To discuss the economic impact for imposing the heavy goods vehicle (HGV) toll system in Germany in January 2005, Doll and Schaffer [9] conducted a study to assess the potential effects of the new system using the I-O model. The research concluds the following points: (1) Neither undesirable price effects nor positive employment effects will play a significant part in overall economic performance. (2) Results of price effects caused by the HGV toll system showed that none of the 70 considered industries is affected by price increase larger than $0.2 \%$; however, the "Road transport" sector suffered a price increase of $5.79 \%$. (3) Results derived from the analysis of employment effects indicate that, if the revenue coming from $\mathrm{HGV}$ toll is reinvested into additional infrastructure projects, about 39,000 new jobs could be created. (4) Form the macroeconomic perspective, the positive effects of improved infrastructure and employment derived from the new HGV toll policy can be assumed to balance the negative impact of cost increases. However, at the microeconomic level, small transport companies will face serious difficulty and may even vanish fro the market. Although this study only handles the road transport issue (HGV toll) and two items (price and employment effects) are explored, it illustrates that the results coming from the I-O model analysis can be used to help policy justification.

Some researchers in Taiwan also employed I-O model to investigate the influence of transportation industry on national economy. As early in 1986, Ho used the data of 1981 I-O table and mainly analyzed the forward and backward linkage effects [11]. She concluded that primary metal products (steel) and chemicals and allied products were the leading sectors at that time; Bearing the relatively higher forward linkage and lower backward linkage effects, transportation industry was with 
strong capacity to support the other sectors. Among the four transportation modes, road transport became the most important sector and produce more than $60 \%$ of total transportation output in 1981. Lien [16] utilized the data derived from the I-O tables of 1976 and 1981 to study the forward and backward linkage effects of transportation sectors (water, road and air transport services) as well as interlinking effects within transportation sectors and between transportation industry and the other industrial sectors. He concluded that (1) the road transportation had overtaken railway services since 1950s in Taiwan; (2) inter-city transportation needed promotion due to the relative lower inter-industrial linkage effects of road transportation; (3) water and air transportation required more expansion to convey the exporting and importing cargoes. Wang [25] analyzed the economic effects of transportation and communications construction in Taiwan by using the data of 1984 I-O table to discuss the forward and backward linkage, income and employment effects. He concluded that (1) public had higher backward linkage effects while transportation and communications had higher forward linkage effects; (2) water and air transportation provided strong support to exporting goods, while road, rail and air transportation focused on domestic travel services; (3) road and warehouse sectors had higher income effects, but water and air transport were with lower income effects; and (4) road and rail transport were having higher employment multiplier, while water and air transport were with lower employment induced effects. Nir and Liang [21] also conducted an inter-industrial linkage study on transportation industry. They classified the transportation into seven sectors including rail, road, water, air, warehouse, travel and transport services. Using the data of 1996, they analyzed the forward and backward linkage, output, income and employment effects. According to empirical results, they concluded that the investment of road transport was the highest, while the rail transport had the higher induced effects of output, income and employment; therefore, the government seemingly needed to reconsider the ratio of construction input on each transport modes.

Table 3 summarizes some information of the papers reviewed, especially the I-O model and empirical data used. Most of the cases only employed single year data in their analysis rather than longitudinal studies. Most researchers only investigated forward and backward linkage effects or employment effects. Among them, Kwak et al. [13] explored maritime industry by using more comprehensive I-O models, which could be a good case to extend their research to include all transportation modes.

\section{RESEARCH METHODOLOGY}

The I-O model is a good research methodology that can be used to explore the influence of the transportation industry on the other sectors [13]. This section briefly introduces the I-O framework used to analyze the inter-industrial linkage of the transportation sector in the national economy.

\section{General Framework of the I-O Model}

The I-O model is a linear, intersectoral model that shows the relationships among the productive sectors of a given economic system. The basic balance equations of the I-O model consisting of $\mathrm{N}$ industry sectors can be expressed as

$$
X_{i}=\sum_{j=1}^{N} x_{i j}+F_{i}=\sum_{j=1}^{N} a_{i j} X_{j}+F_{i}
$$

or

$$
X_{j}=\sum_{i=1}^{N} x_{i j}+V_{j}=\sum_{i=1}^{N} r_{i j} X_{i}+V_{j}
$$

where $X_{i}$ is the total gross output in sector $i=1,2, \ldots, \mathrm{N}$. $a_{i j}\left(=x_{i j} / X_{j}\right)$ are the direct input or technical coefficients that divide $x_{i j}$, the inter-industry purchases of producing sector $i$ from supply sector $j$, by $X_{j}$ total gross output in sector $j$. $r_{i j}\left(=x_{i j} / X_{i}\right)$ are the direct output coefficients that divide $x_{i j}$, the inter-industry purchases of producing sector $i$ from supply sector $j$, by $X_{j}$ total gross output in sector $i . F_{i}$ is the final demand for products in sector $i$, and $V_{j}$ is the final value added by sector $j$. Thus, Eq. (1) describes the demand-side (or demand-driven) model as viewed vertically in the I-O tables, while Eq. (2) expresses the supply-side (or supply-driven) model as viewed horizontally [13].

\section{Inter-Industry Linkage Analysis}

In the framework of an I-O model, production by a particular sector has two types of economic effects on the other sectors in the economy: (1) the backward linkage effect and the (2) forward linkage effect [18]. The backward linkage effect is represented as the power of dispersion (POD), which is the average of $n$ elements in column $j$ divided by the average of all $n^{2}$ elements in the Leontief inverse matrix. Similarly, the forward linkage effect is expressed as the sensitivity of dispersion (SOD), which is the average of $n$ elements in row $i$ divided by the average of all $n^{2}$ elements in the Leontief inverse matrix [10]. Let $b_{i j}$ be the elements of the Leontief inverse matrix. The mathematical calculation of the forward linkage effect $\left(B_{i}^{f}\right)$ and backward linkage effect $\left(F_{j}^{b}\right)$ can then be expressed as $B_{i}^{f}=\frac{\sum_{j=1}^{n} b_{i j}}{\frac{1}{n} \sum_{i=1}^{n} \sum_{j=1}^{n} b_{i j}}$ and $F_{j}^{b}=\frac{\sum_{i=1}^{n} b_{i j}}{\frac{1}{n} \sum_{i=1}^{n} \sum_{j=1}^{n} b_{i j}}$, respectively.

Comparison of the strengths of the backward and forward linkages for the sectors in a single economy provides one mechanism for identifying the "key" or "leading" sectors in that economy and for grouping sectors into spatial clusters [18]. Focusing on the transportation industry, the backward linkage effect means that the production activities of the individual transportation sector may induce greater use of other sectors as an input for transportation production. On the other hand, the 
forward linkage effect indicates that transportation production may be used as an input for other sectors in their own production. Forward and backward linkage effects are then useful in assessing the impact of the transportation sector on the national economy as a whole [13].

\section{Exogenous Considerations in I-O Analysis}

Han et al. [10] and Kwak et al. [13], applying Miller and Blair's [18] research further, proposed that the standard demand-driven I-O model is unable to assess exactly the effects of new production activity in either the electric power industry or the maritime industry on all other sectors of the economy because changes in the final demand come about as a result of forces outside the model (e.g., changes in consumer taste and government purchases). Therefore, the individual electric power sector or maritime sector needs to be handled exogenously and put into the final group. The same principle can be applied to analyze the role of the transportation industry in the national economy.

According to Yoo et al. [26], Eq. (1) can be rewritten in an abbreviated matrix form as $X=(I-A)^{-1} F$. I denotes the $N \times N$ identity matrix, and $(I-A)^{-1}$ is called the Leontief inverse matrix, where elements $\left(b_{i j}=\partial X_{i} / \partial F_{i}\right)$ represent the total direct and indirect outputs in sector i per unit of the final demand in sector $j$. To treat the individual maritime sector as exogenous, we add subscript ' $\mathrm{e}$ ' to the new matrices and subscript ' $M$ ' to vectors related to the individual transportation sector to give $X_{e}=$ $\left(I-A_{e}\right)^{-1}\left(F_{e}+A_{M} X_{M}\right)$. Assuming $\Delta F_{e}=0$, Eq. (3) then yields

$$
\Delta X_{e}=\left(I-A_{e}\right)^{-1} A_{M} \Delta X_{M}
$$

This study utilizes Eq. (3) to analyze the essential relationship of inter-industries for efficient production, with the transportation sector as an infrastructure, and to evaluate the impact of a change in the transportation supply investment of the five transportation sectors on the output of all the other sectors in Taiwan, that is, the production-inducing effect.

As the conventional I-O analysis focuses on analyzing the impacts of backward linkage and may not be appropriate when dealing with the impact from forward linkage, the supplydriven I-O model was developed to tackle the direct and indirect effects of supply restrictions. According to Yoo et al. [26], Eq. (2) can be rewritten in an abbreviated matrix form as $X^{\prime}=V^{\prime}(I-R)^{-1}$. A prime $\left({ }^{\prime}\right)$ denotes the transpose of the given matrix, and $\mathrm{R}$ is the output of coefficient matrix. $(I-R)^{-1}$ is the output inverse matrix, where elements $\left(q_{i j}=\partial X_{j} / \partial V_{i}\right)$ represent the total direct and indirect requirements in sector $j$ per unit of the final value added in sector $i$. As in the case of the demand-driven I-O model, treating the transportation sector as exogenous and assuming that there is no change of value added in all other sectors will yield

$$
\Delta X_{e}^{\prime}=R_{M} \Delta X_{M}\left(I-R_{e}\right)^{-1}
$$

Eq. (4) can be used to assess the impacts of a unit shortage

\begin{tabular}{|c|c|}
\hline Sector & Sub-sectors \\
\hline Rail transportation & $\begin{array}{l}\text { Railway passenger services } \\
\text { Mass rapid transit passenger services } \\
\text { Railway freight services } \\
\text { Railway auxiliary services } \\
\end{array}$ \\
\hline Road transportation & $\begin{array}{l}\text { Passenger services } \\
\text { Freight services } \\
\text { Private freight carriage } \\
\text { Road transport auxiliary services }\end{array}$ \\
\hline Water transportation & $\begin{array}{l}\text { Passenger services } \\
\text { International freight services } \\
\text { Domestic freight services } \\
\text { Water transport auxiliary services }\end{array}$ \\
\hline Air transportation & $\begin{array}{l}\text { Passenger services } \\
\text { Freight services } \\
\text { Other air transport services (including } \\
\text { aerial tourism, survey, photographing, } \\
\text { fire-fighting and searching) } \\
\text { Air transport auxiliary services }\end{array}$ \\
\hline Warehousing service & $\begin{array}{l}\text { General warehousing services } \\
\text { Frozen warehousing }\end{array}$ \\
\hline $\begin{array}{l}\text { Other transportation } \\
\text { services }\end{array}$ & $\begin{array}{l}\text { Customs clearance services } \\
\text { Travel services } \\
\text { Transport forwarding services } \\
\text { Pickup and delivery services } \\
\text { Express or courier services } \\
\text { Other transport services (such as: parking, } \\
\text { cargo inspection and tally, and container } \\
\text { freight station services, etc.) }\end{array}$ \\
\hline
\end{tabular}

Table 4. Transportation sector classification.

in the individual transportation sector on the output of all other sectors and be employed as a basis to define the shortage or failure of transportation production.

According to Miller and Blair [18], structural relationships between sectors in an economy can perhaps be measured most accurately in physical units. This can at least eliminate the influence of prices. The Leontief price model can meet the purpose of tracing through the economy-wide repercussions of changes in the prices of exogenous inputs. Following the old practice, each individual transportation sector is treated as exogenous and is placed in the primary inputs group. Without price changes in the value-added sector, the conventional Leontief price model is written as

$$
\Delta \vec{P}=\left(I-A_{e}^{\prime}\right)^{-1} \hat{A}_{M} \Delta \vec{P}_{M}
$$

where $\vec{P}$ is the matrix of normalized prices. If we assume that the cost change of each sector can be completely transferred and the annual production of each sector is given, Eq. (5) can be used to assess the wholesale price change on the economic system caused by the cost change of the transportation sector [13].

\section{I-O Data Used}

Five sets of I-O domestic tables (i.e., 1991, 1996, 2001, 2004 and 2006) available for Taiwan were used. For the transpor- 
Table 5. Forward linkage effects (sensitivity of dispersion).

\begin{tabular}{|c|c|c|c|c|c|c|c|c|c|c|c|}
\hline & Year & \multicolumn{2}{|c|}{1991} & \multicolumn{2}{|c|}{1996} & \multicolumn{2}{|c|}{2001} & \multicolumn{2}{|c|}{2004} & \multicolumn{2}{|c|}{2006} \\
\hline & Sector & Value & Rank & Value & Rank & Value & Rank & Value & Rank & Value & Rank \\
\hline 1 & Agriculture and forestry & 1.0353 & 11 & 1.0764 & 10 & 0.9917 & 11 & 0.9256 & 13 & 0.6693 & 14 \\
\hline 2 & Mining and quarrying & 0.8030 & 20 & 0.7814 & 21 & 0.7731 & 23 & 0.7396 & 24 & 0.6026 & 16 \\
\hline 3 & Processed food & 0.8769 & 17 & 0.8996 & 17 & 0.8313 & 21 & 0.7888 & 20 & 0.5483 & 19 \\
\hline 4 & Textiles and textile products & 1.0201 & 12 & 0.9472 & 13 & 0.9483 & 12 & 0.9100 & 14 & 0.5973 & 17 \\
\hline 5 & Paper and wood products & 1.2440 & 8 & 1.0719 & 11 & 1.0353 & 9 & 0.9767 & 10 & 0.8294 & 9 \\
\hline 6 & Printing and publishing & 0.7809 & 22 & 0.7777 & 22 & 0.7534 & 24 & 0.7616 & 22 & 0.4390 & 26 \\
\hline 7 & Petroleum and coal products & 1.2750 & 7 & 1.2109 & 7 & 1.4120 & 6 & 1.4894 & 6 & 2.2405 & 2 \\
\hline 8 & Chemicals and allied products & 2.0904 & 1 & 1.8564 & 2 & 1.9311 & 2 & 2.1101 & 3 & 8.9984 & 1 \\
\hline 9 & Nonmetal mineral products & 0.9487 & 14 & 0.9300 & 15 & 0.8374 & 20 & 0.8178 & 18 & 0.8453 & 8 \\
\hline 10 & Primary metal products & 1.9283 & 2 & 1.7801 & 4 & 1.6447 & 4 & 1.9060 & 4 & 1.3445 & 6 \\
\hline 11 & Fabricated metal products & 0.9917 & 13 & 0.9461 & 14 & 0.9374 & 13 & 0.8696 & 15 & 0.6458 & 15 \\
\hline 12 & General machinery and equipment & 0.7904 & 21 & 0.7562 & 24 & 0.7811 & 22 & 0.7822 & 21 & 0.4884 & 24 \\
\hline 13 & Electric and electronic products & 1.0428 & 10 & 1.1375 & 8 & 1.0944 & 8 & 1.0548 & 8 & 0.6855 & 12 \\
\hline 14 & Precision instruments and equipment & 0.6271 & 31 & 0.6305 & 32 & 0.6252 & 31 & 0.5943 & 31 & 0.3770 & 30 \\
\hline 15 & Transportation equipment & 1.0712 & 9 & 1.0780 & 9 & 1.0291 & 10 & 0.9542 & 11 & 0.4889 & 23 \\
\hline 16 & Miscellaneous manufacturing products & 0.6679 & 26 & 0.6679 & 27 & 0.6393 & 27 & 0.6144 & 27 & 0.6878 & 10 \\
\hline 17 & Electric and gas services & 1.3828 & 6 & 1.3591 & 6 & 1.3203 & 7 & 1.2089 & 7 & 1.6622 & 4 \\
\hline 18 & Construction & 0.9417 & 15 & 0.9747 & 12 & 0.8852 & 16 & 0.8414 & 16 & 0.6865 & 11 \\
\hline 19 & Wholesale and retail trade & 1.5574 & 4 & 1.8558 & 3 & 1.5034 & 5 & 1.4936 & 5 & 2.1340 & 3 \\
\hline 20 & Catering and accommodations & 0.6423 & 29 & 0.6515 & 30 & 0.6276 & 30 & 0.6001 & 30 & 0.4314 & 27 \\
\hline 21 & Communication and postal services & 0.7634 & 23 & 0.7978 & 20 & 0.8865 & 15 & 0.9409 & 12 & 0.5734 & 18 \\
\hline 22 & Finance and insurance & 1.8248 & 3 & 1.9261 & 1 & 2.3083 & 1 & 2.2539 & 1 & 1.0694 & 7 \\
\hline 23 & Real estate and business services & 1.4505 & 5 & 1.5210 & 5 & 1.8699 & 3 & 2.2202 & 2 & 1.4022 & 5 \\
\hline 24 & Public administration and defense & 0.5977 & 33 & 0.6088 & 33 & 0.5948 & 33 & 0.5662 & 33 & 0.4767 & 25 \\
\hline 25 & Education and health services & 0.7074 & 25 & 0.7211 & 25 & 0.8465 & 19 & 0.7607 & 23 & 0.5013 & 21 \\
\hline 26 & Social and personal services & 0.8496 & 19 & 0.9075 & 16 & 0.8661 & 17 & 1.0499 & 9 & 0.5090 & 20 \\
\hline 27 & Dummy sector & 0.9102 & 16 & 0.8572 & 19 & 0.8868 & 14 & 0.8193 & 17 & 0.3555 & 33 \\
\hline 28 & Rail transportation & 0.6239 & 32 & 0.6343 & 31 & 0.6160 & 32 & 0.5833 & 32 & 0.3752 & 31 \\
\hline 29 & Road transportation & 0.8714 & 18 & 0.8792 & 18 & 0.8577 & 18 & 0.8121 & 19 & 0.6742 & 13 \\
\hline 30 & Water transportation & 0.6472 & 28 & 0.6778 & 26 & 0.6388 & 28 & 0.6307 & 26 & 0.3996 & 28 \\
\hline 31 & Air transportation & 0.6355 & 30 & 0.6532 & 29 & 0.6406 & 26 & 0.6016 & 29 & 0.3742 & 32 \\
\hline 32 & Warehouse service & 0.6584 & 27 & 0.6600 & 28 & 0.6344 & 29 & 0.6022 & 28 & 0.4990 & 29 \\
\hline 33 & Other transportation services & 0.7421 & 24 & 0.7671 & 23 & 0.7524 & 25 & 0.7204 & 25 & 0.3868 & 22 \\
\hline
\end{tabular}

tation sector-based analysis, as indicated in Table 4 the five original tables were aggregated into 33 sector tables including six transportation industry sub-sectors according to the previous researcher's classification [2, 11, 16, 21, 25], such as rail, road, water, air, warehousing service, and other transportation services. Due to the "other transportation services" include some different transportation auxiliary services (such as forwarding, travel, courier, and delivery, etc.) and hardly can be considered as an individual sector, it will not be discussed in the latter exogenous analysis (i.e., production-inducing effect, supply-shortage effect and price impact).

\section{EMPIRICAL RESULTS}

\section{Inter-Industry Linkage Effects}

As indicated in Table 5, the forward linkage effects of the transportation sectors are relatively lower than those of other sectors, which means that the transportation sectors are less stimulated by the overall industrial growth than other sectors during an economic boom. For the transportation sectors, no big changes occurred in the forward linkage effects from 1991 to 2006. This also implies that, in general, the transportation sector is not significantly influenced by business fluctuations but is a vital input to national economy. However, on the evidence of ranking elevated from the 18th in 1991 to the 13th in 2006, the road transportation was getting more importance to support the other sectors in national economy. Table 6 shows the backward linkage effects of all sectors. Road, rail and air transportation are with higher ranking of backward linkage effects in 2006; in particular, both road and air transportation sharply increase their backward linkage effects over recent years.

Inter-industry linkage effect analysis can provide implications on the structure of an industry in the national economy. 
Table 6. Backward linkage effects (power of dispersion).

\begin{tabular}{|c|c|c|c|c|c|c|c|c|c|c|c|}
\hline & Year & \multicolumn{2}{|c|}{1991} & \multicolumn{2}{|c|}{1996} & \multicolumn{2}{|c|}{2001} & \multicolumn{2}{|c|}{2004} & \multicolumn{2}{|c|}{2006} \\
\hline & Sector & Value & Rank & Value & Rank & Value & Rank & Value & Rank & Value & Rank \\
\hline 1 & Agriculture and forestry & 1.0994 & 11 & 1.1675 & 10 & 1.1157 & 12 & 1.0173 & 14 & 0.9223 & 17 \\
\hline 2 & Mining and quarrying & 0.8727 & 21 & 0.8323 & 27 & 0.8077 & 30 & 0.7916 & 30 & \begin{tabular}{l|l}
1.2686 \\
\end{tabular} & 7 \\
\hline 3 & Processed food & 1.2398 & 3 & 1.2805 & 2 & 1.2298 & 5 & 1.1969 & 7 & 0.9870 & 13 \\
\hline 4 & Textiles and textile products & 1.2810 & 2 & 1.2662 & 3 & 1.3059 & 1 & 1.3177 & 2 & 1.4580 & 6 \\
\hline 5 & Paper and wood products & 1.0857 & 12 & 1.0647 & 14 & 1.0998 & 13 & 1.1357 & 10 & 0.9623 & 14 \\
\hline 6 & Printing and publishing & 1.0640 & 13 & 1.0292 & 16 & 1.0113 & 16 & 0.9981 & 16 & 0.9072 & 18 \\
\hline 7 & Petroleum and coal products & 0.7056 & 33 & 0.7001 & 33 & 0.7048 & 33 & 0.6777 & 33 & 0.6946 & 24 \\
\hline 8 & Chemicals and allied products & 1.1533 & 9 & 1.1097 & 12 & 1.1628 & 7 & 1.1471 & 9 & 2.3239 & 1 \\
\hline 9 & Nonmetal mineral products & 1.0629 & 14 & 1.0745 & 13 & 1.0878 & 14 & 1.0157 & 15 & 1.8695 & 2 \\
\hline 10 & Primary metal products & 1.2094 & 6 & 1.2268 & 4 & 1.2572 & 3 & 1.2445 & 4 & 1.0237 & 11 \\
\hline 11 & Fabricated metal products & 1.2134 & 5 & 1.1843 & 9 & 1.2356 & 4 & 1.2625 & 3 & 1.0384 & 10 \\
\hline 12 & General machinery and equipment & 1.2020 & 7 & 1.1876 & 8 & 1.1539 & 9 & 1.1618 & 8 & 0.8848 & 20 \\
\hline 13 & Electric and electronic products & 1.0240 & 15 & 1.0009 & 17 & 0.9809 & 17 & 0.9385 & 18 & 0.7142 & 23 \\
\hline 14 & Precision instruments and equipment & 0.9973 & 17 & 1.0526 & 15 & 1.0287 & 15 & 0.9924 & 17 & 0.8944 & 19 \\
\hline 15 & Transportation equipment & 1.1384 & 10 & 1.1673 & 11 & 1.1452 & 10 & 1.1136 & 12 & 0.9513 & 15 \\
\hline 16 & Miscellaneous manufacturing products & 1.2002 & 8 & 1.1919 & 6 & 1.1417 & 11 & 1.1034 & 13 & 0.9314 & 16 \\
\hline 17 & Electric and gas services & 0.9033 & 18 & 0.9309 & 18 & 0.8762 & 22 & 0.8248 & 27 & 1.1588 & 8 \\
\hline 18 & Construction & 1.2312 & 4 & 1.1982 & 5 & 1.1838 & 6 & 1.2202 & 5 & 1.7519 & 4 \\
\hline 19 & Wholesale and retail trade & 0.8638 & 24 & 0.8573 & 23 & 0.8344 & 27 & 0.8298 & 25 & 0.6364 & 26 \\
\hline 20 & Catering and accommodations & 0.8901 & 19 & 0.8891 & 19 & 0.8677 & 23 & 0.8504 & 22 & 0.8267 & 21 \\
\hline 21 & Communication and postal services & 0.7120 & 32 & 0.7062 & 32 & 0.8486 & 24 & 0.8373 & 24 & 0.6200 & 29 \\
\hline 22 & Finance and insurance & 0.8399 & 29 & 0.8069 & 30 & 0.8765 & 21 & 0.9067 & 20 & 0.5426 & 32 \\
\hline 23 & Real estate and business services & 0.8561 & 26 & 0.8541 & 24 & 0.8309 & 28 & 0.8285 & 26 & 0.6306 & 27 \\
\hline 24 & Public administration and defense & 0.8529 & 28 & 0.8246 & 28 & 0.7298 & 32 & 0.6791 & 32 & 0.5633 & 31 \\
\hline 25 & Education and health services & 0.8118 & 31 & 0.7732 & 31 & 0.7688 & 31 & 0.7421 & 31 & 0.6293 & 28 \\
\hline 26 & Social and personal services & 0.8676 & 23 & 0.8585 & 22 & 0.8382 & 26 & 1.1170 & 11 & 0.6829 & 25 \\
\hline 27 & Dummy sector & 1.0178 & 16 & 1.1914 & 7 & 1.1614 & 8 & 1.5419 & 1 & 0.3555 & 33 \\
\hline 28 & Rail transportation & 1.3069 & 1 & 1.2883 & 1 & 1.2977 & 2 & 1.2087 & 6 & 1.4749 & 5 \\
\hline 29 & Road transportation & 0.8553 & 27 & 0.8874 & 20 & 0.9152 & 20 & 0.9231 & 19 & 1.8077 & 3 \\
\hline 30 & Water transportation & 0.8813 & 20 & 0.8524 & 25 & 0.8176 & 29 & 0.8150 & 29 & 0.5973 & 30 \\
\hline 31 & Air transportation & 0.8321 & 30 & 0.8193 & 29 & 0.9237 & 18 & 0.8419 & 23 & 1.1028 & 9 \\
\hline 32 & Warehouse service & 0.8719 & 22 & 0.8744 & 21 & 0.9187 & 19 & 0.9021 & 21 & 0.7802 & 12 \\
\hline 33 & Other transportation services & 0.8571 & 25 & 0.8519 & 26 & 0.8419 & 25 & 0.8168 & 28 & 1.0061 & 22 \\
\hline
\end{tabular}

According to Lin and Chang [17], if industries have both power and sensitivity of dispersion values greater than one for both forward and backward linkage effects, these industries play crucial roles in the economic development and in supporting other industries (forward linkage effect), as well as in boosting other industries (backward linkage effect). On the other hand, if industries have both power and sensitivity of dispersion values smaller than one for both forward and backward linkage effects, these industries have difficulty in supporting and boosting other industries. The results of this study indicate that the transportation industry may generally have more strength in absorbing products of related industries rather than in being used as an input by other industries. Moreover, among the six transportation services, the road, rail and air transportation sectors (with higher backward linkage effect) have a relatively strong capacity for pulling in other industries; especially, the road and air modes swiftly getting higher backward linkage effect in 2006 seemingly indicate that these two sectors become more important over recent years. Besides, the road transportation (with higher forward and backward linkage effects) has comparatively more strength to support and promote the other industries.

\section{Production-Inducing Effects}

The production-inducing effects of the transportation sector are shown in Table 7 and Fig. 1, where important results can be observed. First, the sum of the effects of NTD1.00 change in transportation investment on the output of other sectors was NTD11.4141 in 2006 (rail transportation-3.1314; road transportation-3.8437; water transportation- 0.5485 ; air transportation-2.0980; and warehousing services-1.7925). Secondly, among the five sectors, road transportation had the highest production-inducing effects (0.4159 to 3.8437$)$ during the period of 1991-2006, followed by rail transportation (1.1132 
Table 7. Production-inducing effects of the transportation sectors.

\begin{tabular}{|c|c|c|}
\hline Sector & Year & Top three sectors with higher production-inducing effects generated by transportation sectors (with value) \\
\hline \multirow{5}{*}{$\begin{array}{l}\text { Rail } \\
\text { transportation }\end{array}$} & 991 & Transportation equipment (0.3208), Construction (0.1925), Finance and insurance (0.1049) \\
\hline & 1996 & Transportation equipment $(0.3030)$, Construction $(0.2197)$, Primary metal products $(0.0721)$ \\
\hline & 2001 & Transportation equipment (0.2865), Construction (0.1757), Finance and insurance $(0.1517)$ \\
\hline & 2004 & Transportation equipment (0.2671), Construction (0.1600), Finance and insurance (0.0911) \\
\hline & 2006 & Chemicals and allied products (1.0523), Miscellaneous manufacturing products $(0.3126)$, Construction $(0.2873)$ \\
\hline \multirow{5}{*}{$\begin{array}{l}\text { Road } \\
\text { transportation }\end{array}$} & 1991 & Chemicals \& allied products $(0.1287)$, Wholesale and retail trade $(0.0523)$, Finance and insurance $(0.0483)$ \\
\hline & 1996 & Chemicals \& allied products $(0.1495)$, Wholesale and retail trade $(0.0561)$, Social and personal services $(0.0547)$ \\
\hline & 2001 & Chemicals \& allied products $(0.2001)$, Finance and insurance $(0.0606)$, Social and personal services $(0.0558)$ \\
\hline & 2004 & Chemicals \& allied products (0.2458), Finance and insurance (0.0767), Social and personal services (2.0589), \\
\hline & 2006 & Chemicals and allied products $(1.0523)$, Petroleum and coal products $(0.5520)$, Wholesale and retail trade $(0.2538)$ \\
\hline \multirow{5}{*}{$\begin{array}{l}\text { Water } \\
\text { transportation }\end{array}$} & 1991 & Real estate $\&$ business services $(0.0724)$, Finance $\&$ insurance $(0.0556)$, Transportation equipments $(0.05319)$ \\
\hline & 1996 & Real estate \& business services $(0.0678)$, Other transportation services $(0.0528)$, Finance and insurance $(0.0384)$ \\
\hline & 2001 & Real estate $\&$ business services $(0.0655)$, Other transportation services $(0.0515)$, Finance and insurance $(0.0461)$ \\
\hline & 2004 & Chemicals \& allied products $(0.0830)$, Real estate $\&$ business services $(0.0594)$, Finance and insurance $(0.0492)$ \\
\hline & 2006 & Chemicals and allied products $(0.2027)$, Wholesale and retail trade $(0.0641)$, Other transportation services $(0.0540)$ \\
\hline \multirow{5}{*}{$\begin{array}{l}\text { Air } \\
\text { transportation }\end{array}$} & 1991 & Chemicals \& allied products $(0.0641)$, Real estate \& business services $(0.0482)$, Transportation equipments $(0.0463)$ \\
\hline & 1996 & Transportation equipments $(0.0477)$, Real estate $\&$ business services $(0.0460)$, Finance and insurance $(0.03650)$ \\
\hline & 2001 & Finance \& insurance $(0.1198)$, Chemicals \& allied products $(0.0970)$, Real estate $\&$ business services $(0.0630)$ \\
\hline & 2004 & Finance \& insurance (0.1159), Real estate \& business services (0.0647), Chemicals \& allied products (0.0601) \\
\hline & 2006 & Chemicals and allied products $(0.9473)$, Petroleum and coal products $(0.2501)$, Wholesale and retail trade $(0.2065)$ \\
\hline \multirow{5}{*}{$\begin{array}{l}\text { Warehousing } \\
\text { services }\end{array}$} & 1991 & Electric and gas services (0.0539), Finance \& insurance (0.0498), Road transportation $(0.0447)$ \\
\hline & 1996 & Electric and gas services (0.0467), Road transportation (0.0422), Finance \& insurance $(0.0386)$ \\
\hline & 2001 & Finance \& insurance (0.0938), Real estate \& business services $(0.0599)$, Chemicals \& allied products $(0.0522)$ \\
\hline & 2004 & Finance \& insurance $(0.1062)$, Real estate $\&$ business services $(0.0658)$, Chemicals \& allied products $(0.0643)$ \\
\hline & 2006 & Chemicals and allied products $(0.7752)$, Petroleum and coal products $(0.2032)$, Electric and gas services $(0.1190)$ \\
\hline
\end{tabular}

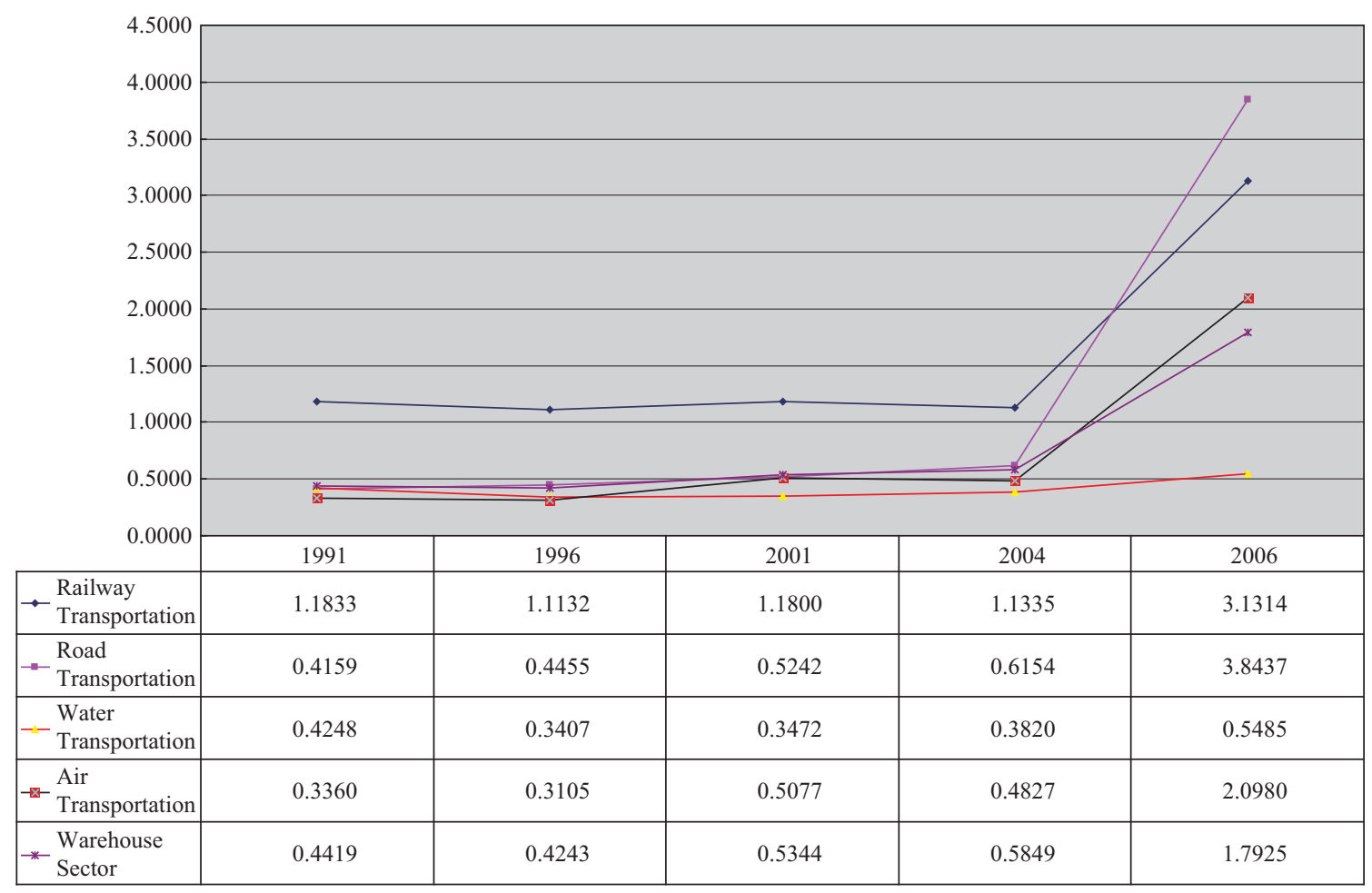

Fig. 1. Production-inducing effects of transportation sectors. 
Table 8. Supply shortage effects of transportation sectors.

\begin{tabular}{|c|c|c|}
\hline Sector & ear & Top three sectors with higher Supply shortage effects generated by transportation sectors (with value) \\
\hline \multirow{5}{*}{$\begin{array}{l}\text { Rail } \\
\text { transportation }\end{array}$} & 91 & ublic administration and defense (0.1887), Processed food (0.0980), Construction $(0.0798)$ \\
\hline & 1996 & ublic administration and defense (0.1703), Construction (0.0973), Electric and electronic products $(0.0948)$ \\
\hline & 2001 & ublic administration and defense (0.0987), Electric and electronic products $(0.0853)$, Finance and insurance $(0.0681)$ \\
\hline & 2004 & $\begin{array}{l}\text { lectric and electronic products }(0.1002) \text {, Public administration and defense }(0.0886) \text {, Real estate and business } \\
\text { ervices }(0.0805)\end{array}$ \\
\hline & 2006 & Chemicals and allied products $(0.1656)$, Electric and electronic products $(0.0915)$, Wholesale and retail trade $(0.0851)$ \\
\hline \multirow{5}{*}{$\begin{array}{l}\text { Road } \\
\text { transportation }\end{array}$} & 91 & onstruction $(0.1100)$, Chemicals and allied products $(0.0585)$, Electric and electronic products $(0.0550)$ \\
\hline & 1996 & Construction (0.1274), Electric and electronic products $(0.0772)$, Chemicals and allied products $(0$. \\
\hline & 2001 & Construction (0.1327), Electric and electronic products (0.0848), Chemicals and alliec \\
\hline & 2004 & ס \\
\hline & 2006 & Chemicals and allied products $(0.2533)$, Construction (0.1456), Electric and electronic produc \\
\hline \multirow{5}{*}{$\begin{array}{l}\text { Water } \\
\text { transportation }\end{array}$} & 1991 & Wholesale and retail trade $(0.0095)$, Warehouse service $(0.005$ \\
\hline & 1996 & Construction $(0.0143)$, Wholesale and retail trade $(0.0122)$, Other transportation services $(0.0072)$ \\
\hline & 2001 & Construction (0.0107), Chemicals and allied products (0.0099), Wholesale and retail trade $(0.0079)$ \\
\hline & 2004 & Chemicals and allied products $(0.0199)$, Construction $(0.0139)$, Primary metal products $(0.0120)$ \\
\hline & 2006 & Chemicals and allied products $(0.0182)$, Construction $(0.0081)$, Primary metal products $(0.0068)$ \\
\hline \multirow{5}{*}{$\begin{array}{l}\text { Air } \\
\text { transportation }\end{array}$} & 1991 & Public administration and defense (0.0448), Wholesale and retail trade $(0.0067)$, Social and personal services $(0.0048)$ \\
\hline & 1996 & $\begin{array}{l}\text { Public administration and defense (0.0105), Wholesale and retail trade (0.0098), Other transportation services } \\
(0.0074)\end{array}$ \\
\hline & 2001 & $\begin{array}{l}\text { Public administration and defense }(0.0103) \text {, Wholesale and retail trade }(0.0070) \text {, Real estate and business services } \\
(0.0065)\end{array}$ \\
\hline & 2004 & $\begin{array}{l}\text { Real estate and business services (0.0095), Public administration and defense }(0.0085) \text {, Social and personal services } \\
(0.0081)\end{array}$ \\
\hline & 2006 & $\begin{array}{l}\text { Wholesale and retail trade }(0.0162) \text {, Real estate and business services }(0.0115) \text {, Electric and electronic products } \\
(0.0107)\end{array}$ \\
\hline \multirow{5}{*}{$\begin{array}{l}\text { Warehousing } \\
\text { services }\end{array}$} & 1991 & Wholesale and retail trade $(0.4855)$, Electric and electronic products $(0.1216)$, Chemicals and allied products $(0.1164$ \\
\hline & 1996 & Wholesale and retail trade $(0.5825)$, Electric and electronic products $(0.1542)$, Chemicals and allied products $(0.0877)$ \\
\hline & 2001 & Wholesale and retail trade $(0.4742)$, Electric and electronic products $(0.1639)$, Chemicals and allied products $(0.0993$ \\
\hline & 2004 & Wholesale and retail trade $(0.5069)$, Electric and electronic products $(0.1728)$, Primary metal products $(0.1319)$ \\
\hline & 2006 & Wholesale and retail trade $(0.6221)$, Chemicals and allied products $(0.1196)$, Electric and electronic products $(0.1027)$ \\
\hline
\end{tabular}

to 3.1314$)$ and air transportation $(0.3105$ to 2.0980$)$. Water transportation had the lowest production-inducing effects (0.3407 to 0.5485$)$, although the shipping industry is well developed in Taiwan [4]. This means that placing more investment on road transportation may provide more help to the production of other sectors. Moreover, the road and air transportation sectors and warehousing sector recorded the higher increase in production-inducing effects during the period of 1991-2006. Finally, conforming to their industrial characteristics in 2006, the chemicals and allied products was the highest production-inducing sector of all five individual transportation sectors.

\section{Supply-Shortage Effects}

The results of the supply-driven model may provide valuable information on the economic effects of the transportation industry supply shortages. The transportation supply also has direct and indirect effects on the production activities of other sectors. The effects of the transportation sector supply shortages are particularly crucial because the transportation industry generates significant effects on other transportationconsuming sectors. Table 8 and Fig. 2 summarize the supply shortage effects of the transportation sectors in Taiwan during the period of 1991-2006, highlighting three major results. (1) The sum of the shortage costs of transportation sectors slightly increased from NTD3.6272 to NTD3.8705 in 1991-2006. The road transportation sector, in particular, demonstrated a bigger increase from NTD0.7537 in 1991 to NTD1.1331 in 2006. However, the rail and water transportation sectors showed a bigger decrease during the same period. (2) Among the five sectors, warehouse services had the highest supply shortage effects (1.6536 to 1.5129) during the period of 1991-2006, followed by road ( 0.7537 to 1.1331$)$ and rail transportation (1.1078 to 0.7747$)$. The water and air transportation sectors had the lowest supply shortage in Taiwan. (3) In 2006, the sectors whose shortage costs were highest in each transporta- 


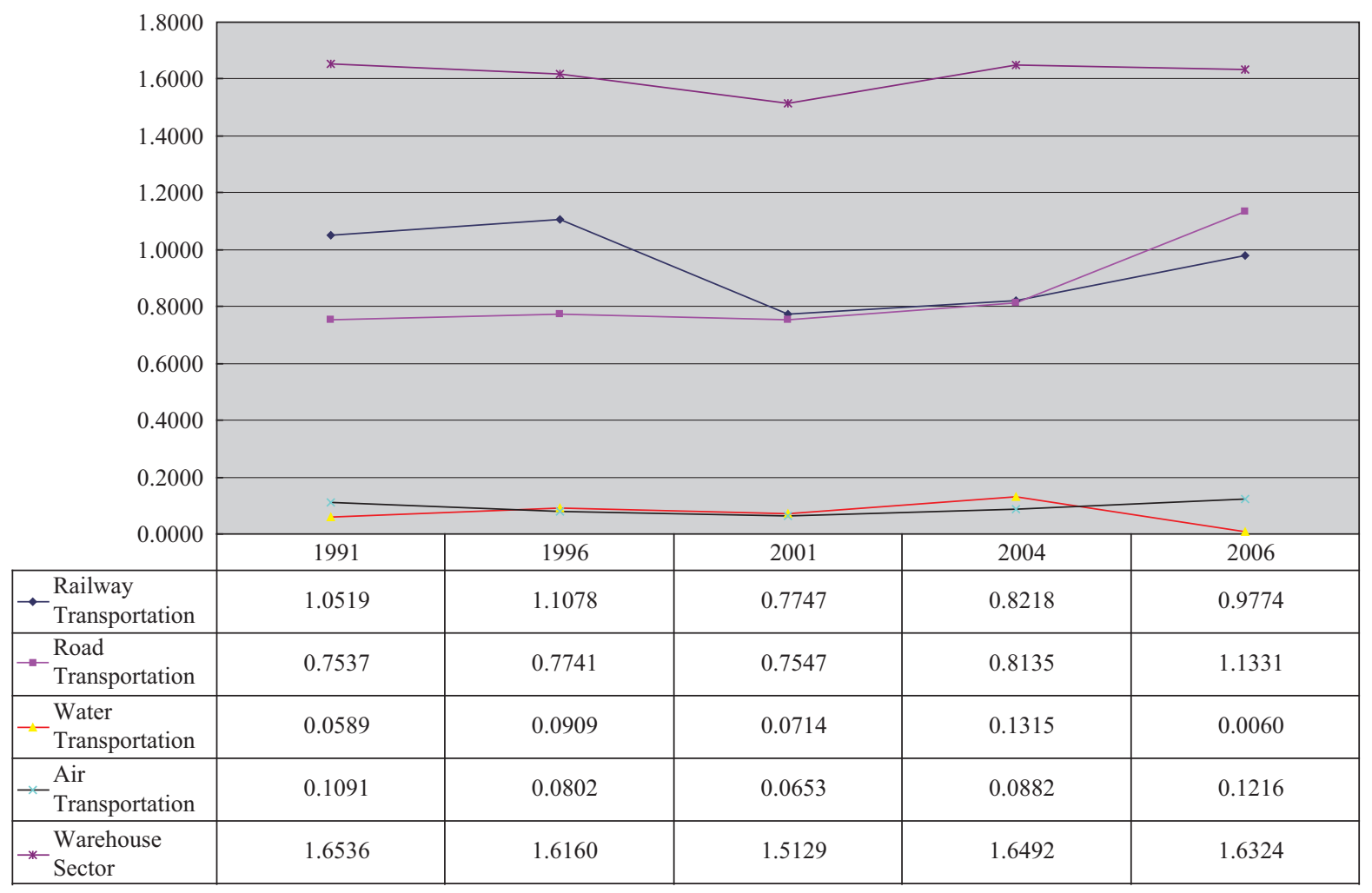

Fig. 2. Supply shortage effects of transportation sectors.

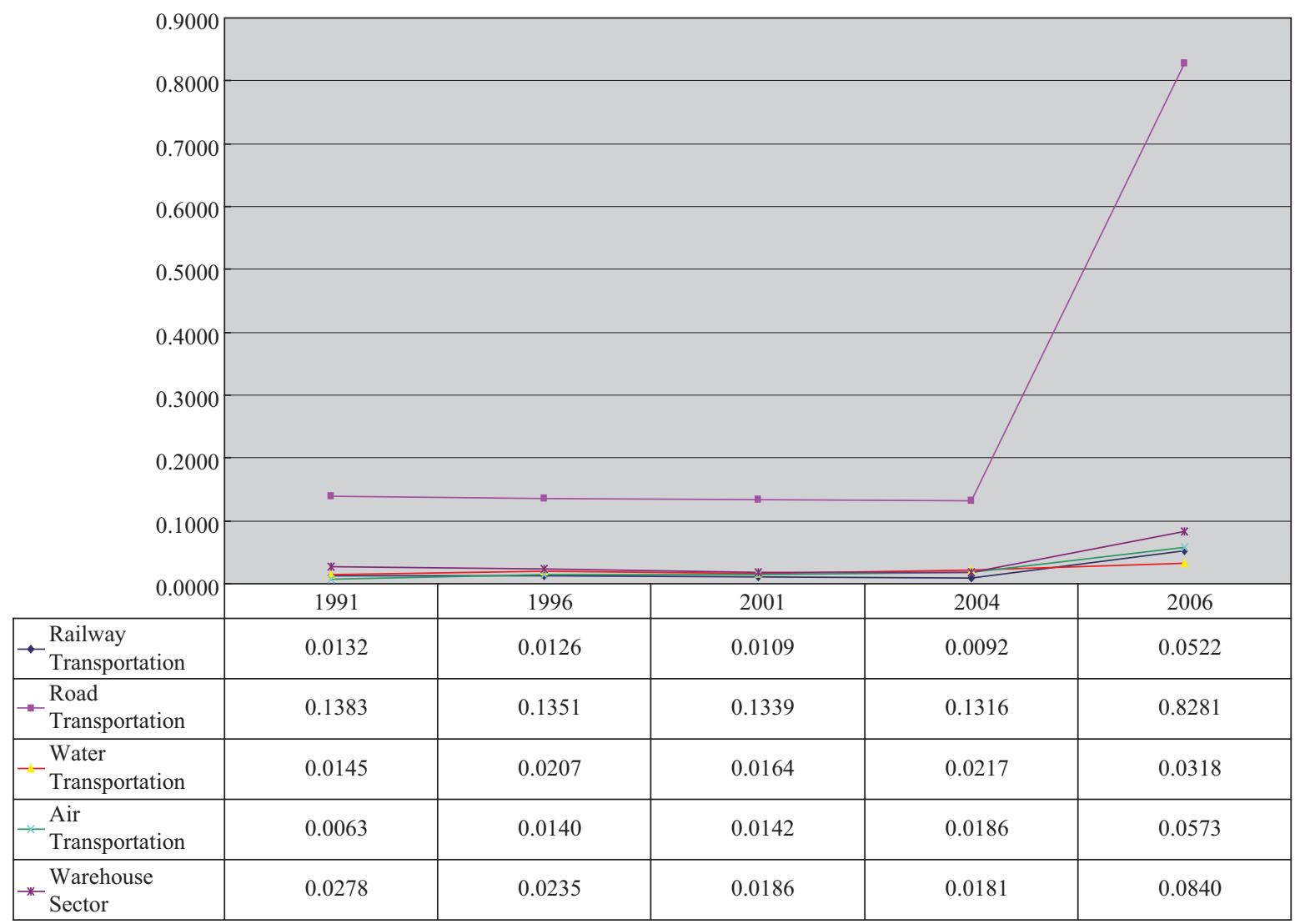

Fig. 3. Sectoral price impact of the $10 \%$ increase in transportation sectors. 
Table 9. Sectoral price impacts by a $\mathbf{1 0 \%}$ increase in the transportation sectors.

\begin{tabular}{|c|c|c|}
\hline Sector & Year & Top three sectors with higher price impacts generated by transportation sectors (with value) \\
\hline \multirow{5}{*}{$\begin{array}{l}\text { Rail } \\
\text { transportation }\end{array}$} & 1991 & Nonmetal mineral products $(0.0425)$, Public administration and defense $(0.0369)$, Processed food $(0.0253)$ \\
\hline & 1996 & Nonmetal mineral products $(0.0406)$, Public administration and defense $(0.0346)$, Processed food $(0.0216)$ \\
\hline & 2001 & $\begin{array}{l}\text { Nonmetal mineral products }(0.0312) \text {, Public administration and defense }(0.0255) \text {, Printing and publishing } \\
(0.0171)\end{array}$ \\
\hline & 2004 & $\begin{array}{l}\text { Nonmetal mineral products }(0.0231) \text {, Public administration and defense }(0.0211) \text {, General machinery and } \\
\text { equipment }(0.0145)\end{array}$ \\
\hline & 2006 & $\begin{array}{l}\text { Chemicals and allied products }(0.0162) \text {, Petroleum and coal products }(0.0034) \text {, Wholesale and retail trade } \\
(0.0033)\end{array}$ \\
\hline \multirow{5}{*}{$\begin{array}{l}\text { Road } \\
\text { transportation }\end{array}$} & 1991 & Warehouse service (0.4476), Nonmetal mineral products $(0.3389)$, Construction $(0.3355)$ \\
\hline & 1996 & Warehouse service (0.4216), Nonmetal mineral products $(0.3426)$, Construction $(0.3274)$ \\
\hline & 2001 & Warehouse service $(0.4628)$, Nonmetal mineral products $(0.4029)$, Construction $(0.3966)$ \\
\hline & 2004 & Rail transportation (0.4662), Warehouse service (0.4598), Construction $(0.3626)$ \\
\hline & 2006 & Chemicals and allied products $(0.2583)$, Warehouse service $(0.0579)$, Petroleum and coal products $(0.0540)$ \\
\hline \multirow{5}{*}{$\begin{array}{l}\text { Water } \\
\text { transportation }\end{array}$} & 1991 & Warehouse service $(0.2813)$, Other transportation services $(0.0501)$, Dummy sector $(0.0171)$ \\
\hline & 1996 & Warehouse service $(0.3453)$, Other transportation services $(0.0848)$, Nonmetal mineral products $(0.0386)$ \\
\hline & 2001 & Warehouse service $(0.3112)$, Nonmetal mineral products $(0.0369)$, Other transportation services $(0.0367)$ \\
\hline & 2004 & Warehouse service (0.2938), Dummy sector (0.0416), Nonmetal mineral products $(0.0366)$ \\
\hline & 2006 & $\begin{array}{l}\text { Chemicals and allied products }(0.0126) \text {, Nonmetal mineral products }(0.0033) \text {, Petroleum and coal products } \\
(0.0027)\end{array}$ \\
\hline \multirow{5}{*}{$\begin{array}{l}\text { Air } \\
\text { transportation }\end{array}$} & 1991 & Warehouse service (0.0394), Other transportation services (0.0340), Public administration and defense $(0.0334)$ \\
\hline & 1996 & Warehouse service (0.2247), Other transportation services (0.0755), Public administration and defense (0.0149) \\
\hline & 2001 & Warehouse service $(0.2450)$, Other transportation services $(0.0179)$, Public administration and defense $(0.0179)$ \\
\hline & 2004 & Warehouse service $(0.2676)$, Other transportation services $(0.0676)$, Dummy sector $(0.0542)$ \\
\hline & 2006 & $\begin{array}{l}\text { Chemicals and allied products }(0.0131) \text {, Communication and postal services }(0.0050) \text {, Other transportation ser- } \\
\text { vices }(0.0036)\end{array}$ \\
\hline \multirow{5}{*}{$\begin{array}{l}\text { Warehousing } \\
\text { services }\end{array}$} & 1991 & Other transportation services $(0.1284)$, Water transportation $(0.1098)$, Air transportation $(0.0938)$ \\
\hline & 1996 & Wholesale and retail trade $(0.0892)$, Water transportation $(0.0875)$, Other transportation services $(0.0859)$ \\
\hline & 2001 & Other transportation services $(0.0827)$, Water transportation $(0.0819)$, Air transportation $(0.0809)$ \\
\hline & 2004 & Water transportation (0.0653), Air transportation $(0.0633)$, Other transportation services $(0.0602)$ \\
\hline & 2006 & Chemicals and allied products $(0.0197)$, Water transportation $(0.0110)$, Wholesale and retail trade $(0.0084)$ \\
\hline
\end{tabular}

tion sector were chemicals and allied products $(0.1656)$ for rail transportation; chemicals and allied products $(0.2533)$ for road transportation; chemicals and allied products (0.0182) for water transportation; wholesale and retail trade $(0.0162)$ for air transportation; and Wholesale and retail trade $(0.6221)$ for warehousing services.

\section{The Sectoral Price Impacts}

As previously mentioned, the modified Leontief price model (Eq. (5)) can be used to assess the wholesale price change on the economic system caused by the cost change of the transportation sector. The sectoral changes due to the $10 \%$ increase in price levels during the period of 1991-2006 are shown in Fig. 3 and Table 9. Except for the road transport, the effects of price changes are relatively small in the period covered by this study. Comparing the five sectors, road transportation has a bigger price impact on other sectors (ranging from 0.1316 to 0.8281 ). For example, if road trans- portation price increased $10 \%$ in 2006, it would cause a $0.2583 \%$ increase in Chemicals and allied products costs, $0.0579 \%$ increase in warehouse service, and $0.0540 \%$ increase in petroleum and coal products (Table 8). The results in Fig. 3 also indicate that the national economy-wide effects of a $10 \%$ increase in the overall transportation sector rates increased from $0.2001 \%$ to $1.0534 \%$. The results also pointed out that the price impact of all five transportation sectors augmented significantly in 2006; in particular, the road transport sector recorded a huge upsurge.

\section{Employment Effects}

Under the I-O framework, the employment multipliers for each sector can be calculated by estimating the relationships between the value of output of a sector and employment in that sector in physical terms [18]. Unemployment has gradually become a serious problem over the years in Taiwan, with the unemployment rate increasing from $1.229 \%$ in 1980 to $6.077 \%$ 


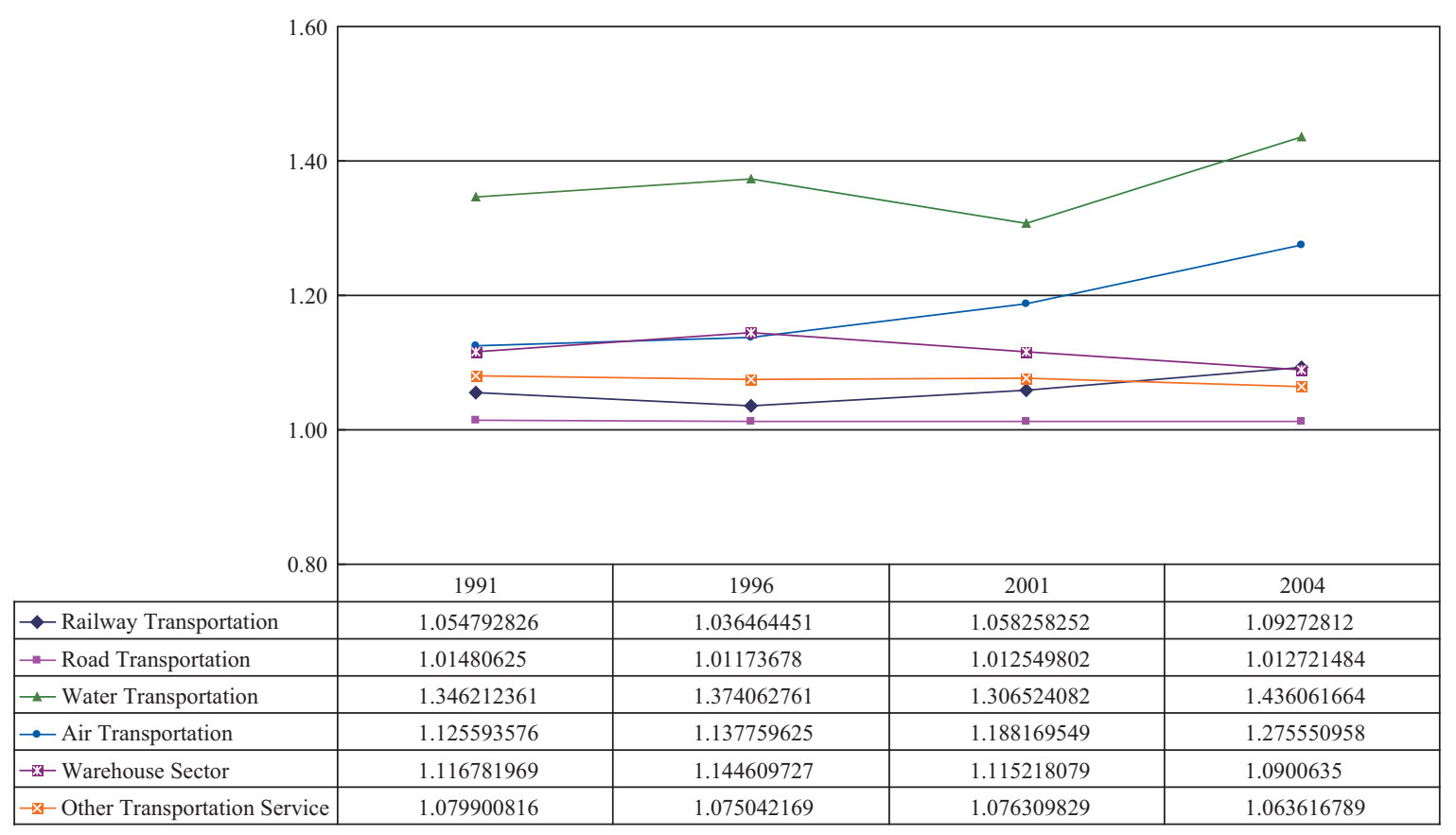

Fig. 4. Employment effects of transportation sectors.

in 2009 [12]. The government expects that the transportation industry should create more jobs along with its development. Fig. 4 shows the employment effects of the transportation sectors during the period of 1991-2004. Two important results can be observed. First is that the water transportation sector has greater values of employment multipliers (increasing from 1.3462 in 1991 to 1.4361 in 2004) among the five transportation sectors, followed by air transportation and warehousing services. The employment effects of the road transportation sector registered the lowest value during the same period. This means that in 2004, with a water transportation output of NTD1 million, the water transportation sector generated an employment of 1.4361 persons. Second is that by putting more investments in water and air transportation sectors, more jobs can be possibly created.

\section{CONCLUSIONS AND DISCUSSIONS}

\section{Conclusions}

This study uses comprehensive I-O analyses, including the demand-driven model, the supply-driven model, the interindustry linkage effect analysis, and the Leontief price model, to investigate the role of the transportation sector in Taiwan's national economy in 1991-2006. Except for the inter-industry linkage effect analysis, each individual sector (as the object of analysis) is considered exogenous to assess the net effects of changes in production or price in each sector only. For research purposes, this paper has demonstrated the feasibility of extending the use of I-O analysis at least for the transportation industry. The results can provide some guidelines for policymakers when making proposals for the transportation in- dustry's investment and construction.

The results are summarized as the following. First, the results of inter-industry linkage indicate that the transportation industry in Taiwan has more strength in absorbing the products of related industries rather than in being used as an input by other industries. Among the six transportation services, the road, rail and air transportation sectors (with higher backward linkage effect) have a relatively strong capacity for pulling in other industries; especially, the road and air modes swiftly getting higher backward linkage effect in 2006 seemingly indicate that these two sectors become more important over recent years. Besides, the road transportation (with a higher forward linkage effect) comparatively has more strength to support the other industries.

Second, the total production-inducing effects of the transportation sector were high and jumped from 2.80 in 1991 to 11.41 in 2006. Moreover, overtaking the rail sector in 2006, road transportation had the highest production-inducing effects (3.8437) among the five transport sectors in 2006. Water transportation had the lowest production-inducing effects (0.3407 to 0.5485$)$, although the shipping industry is well developed in Taiwan. In addition, the road and air transportation sectors and warehousing sector recorded the higher increase in production-inducing effects during the period of 1991-2006; that seemingly pointed out these three sectors would be more important and provide more help to the production of the other sectors in the future.

Third, the total supply-shortage effects of transportation sectors slightly increased from 3.6272 to 3.8705 in 1991-2006. Among the five sectors, warehousing services had the highest supply shortage effects (1.6536 to 1.5129$)$ during the period of 
1991-2006. In the $21^{\text {st }}$ century, logistics/supply chain management has been emphasized as crucial to business operation and national economic development. Warehousing is one of the vital activities of logistics management [22]. Taiwan government should then provide sufficient warehousing services to avoid the increase in production costs due to the warehousing services-consuming sectors. Fourth, except for the road transport, the economy-wide price effects in the period covered by this study were relatively small. In 1991-2006, due to the sharp increase of road transport in 2006, the sum of price effects of a $10 \%$ increase in the overall transportation sectors rates also increased from $0.2001 \%$ to $1.0534 \%$. Nevertheless, the price impact of water transportation increased from 0.0145 to 0.0318 , while that of air transportation also increased from 0.0063 to 0.0573 during the period of 1991-2006. Finally, the water transportation sector had greater employment effects, followed by air transportation and warehousing services. This means that by putting more investments in water and air transportation sectors, more jobs can be possibly created.

Based on the aforementioned conclusions, some suggestions for implementing the recent transportation projects are as follows: (1) In view of the growing importance of road and air transport sectors in national economy, all the projects listed in the Plan for Expanding Investment in Public Works to Revitalize the Economy (including the expansion of super highway networks and the enhancement of function and service quality of Taoyuan International Airport) [5] are required to be completed as soon as possible; (2) Due to the highest supply shortage effects among the five transportation sectors, increase of warehousing facilities and services in logistics centers and free trade zones are needed to help promote Taiwan as an international logistics/supply chain centers; and (3) In consideration of the water transportation having greater employment effects and importance to convey importing and exporting goods, continued investment on sea transport facilities (such as passenger ferry terminal in Kaohsiung port) in Taiwan and its off-shore islands (Penghu, Kinmen and Matsu) are still necessary.

\section{Discussions}

As discussed previously the I-O model is good framework to analyze the interdependence of industries in an economy, while some points are worthy to be noted. First, the analysis is constrained by the availability of data (the I-O tables). Usually, the I-O tables are published by governmental agency due to the huge costs to compile the raw materials; because of that, there is a time-lag problem. In the case of Taiwan, almost three years lag to publish the I-O tables (e.g., the 2006 data was only available in early 2010). Second, a lot of the researches only employed single year data in their analysis rather than longitudinal studies. Under such circumstances, there is no possibility to conduct the inter-temporal comparison of the results. Using the long-term data to conduct I-O analysis was suggested by some researchers, such as Kwak et al. [13] and Han et al. [10].

\section{REFERENCES}

1. Bryan, J., Munday, M., Pickernell, D., and Roberts, A., "Assessing the economic significance of port activity: evidence from ABP Operations in industrial South Wales," Maritime Policy and Management, Vol. 33, No. 4, pp. 371-386 (2006).

2. Chang, Y.-H., Modern Transportation, Hwa-Tai Publishing, Taipei (2005). (in Chinese)

3. Chiang, C. A. and Wainwright, K., Fundamental Methods of Mathematic Economics, 4th Ed., Mc-Graw Hill, United States (2005).

4. Chiu, R.-H., "Liberalization of shipping in Taiwan," Marine Policy, Vol. 31, pp. 258-265 (2007).

5. Council for Economic Planning and Development, Executive Yuan, Plan for Expanding Investment in Public Works to Revitalize the Economy, Taipei, Taiwan (2008). (http://www.ey.gov.tw/public/Data/99211149771. pdf)

6. Coyle, J. J., Bardi, E. J., and Novack, R. A., Transportation, 5th Ed., South-Western College Publishing, United States and Singapore (2000).

7. Directorate-General of Budget, Accounting and Statistics, Executives Yuan, ROC, Input-Output Tables 1991, 1996, 2001, 2004, 2006, Taipei, Taiwan.

8. Directorate-General of Budget, Accounting and Statistics (DGBAS), Executives Yuan, ROC, Quarterly National Economic Trends, Taipei, Taiwan (2007).

9. Doll, C. and Schaffer, A., "Economic impact of the introduction of the German HGV toll system," Transport Policy, Vol. 14, pp. 49-58 (2007).

10. Han, S. Y., Yoo, S. H., and Kwak, S. J., "The role of the four electric power sectors in the Korean national economy: an input-output analysis," Energy Policy, Vol. 32, No. 13, pp. 1531-1543 (2004).

11. Ho, I.-S., "Investigating the linkage between transportation industry and Macro-economic growth," Journal of Transportation Planning, Vol. 15, No. 4, pp. 519-534 (1986). (in Chinese)

12. Index Mundi (2010) Taiwan unemployment rate, viewed on 12 January 2009, http://www.indexmundi.com/.

13. Kwak, S. J., Yoo, S. H., and Chang, J. I., "The role of the maritime industry in the Korean national economy: an input-output analysis," Marine Policy, Vol. 29, No. 4, pp. 371-383 (2005).

14. Lee, T. W., Chang, Y. T., and Shin, S. H., "A comparative study on economic effects on Korean economy by transport mode using input-output analysis," The Journal of Shipping and Logistics, Vol. 46, pp. 47-67 (2006).

15. Leontief, W., Input-Output Economics, Oxford University Press, New York (1966).

16. Lien, Y.-W., "A study on inter-industrial linkage of transportation industry in Taiwan," Monthly Journal of Bank of Taiwan, Vol. 37, No. 1, pp. 144185 (1986). (in Chinese)

17. Lin, J. S. and Chang, F. Y., "Linkage effects and environmental impact from oil consumption industries in Taiwan," Journal of Environmental Management, Vol. 49, No. 4, pp. 393-411 (1997).

18. Miller, R. E. and Blair, P. D., Input-Output Analysis: Foundations and Extensions, Prentice-Hall Inc., New Jersey (1985).

19. Ministry of Transportation and Communications (MOTC), Transportation Policy White Paper, Taipei, Taiwan (2002).

20. Miyazawa, K., "Internal and external matrix multipliers in the inputoutput model," Hitosubashi Journal of Economics, Vol. 7, No. 1, pp. 1737 (1966).

21. Nir, A.-S. and Liang, G.-S., "Transport sector construction inter-industry effects positive study in Taiwan area," Maritime Research Journal, Vol. 14, pp. 1-28 (2003). (in Chinese)

22. Stock, J. R. and Lambert, D. M., Strategic Logistics Management, 4th Ed., McGraw-Hill, Boston and Taipei (2001).

23. Van Der Linden, J. A., "The economic impact study of maritime policy issues: application to the German case," Maritime Policy and Management, Vol. 28, No. 1, pp. 33-54 (2001).

24. Velazquez, E., "An input-output model of water consumption: analyzing intersectoral water relationships in Andalusia," Ecological Economics, Vol. 56, pp. 226-240 (2006). 
25. Wang, T.-F., "Analyzing the economic effects of transportation and communications construction,” Economic Research, Vol. 30, pp. 79-125 (1990). (in Chinese)

26. Yoo, S. H. and Yoo, T. H., "The role of the nuclear power generation in the Korean national economy: an input-output analysis," Progress in
Nuclear Energy, pp. 1-7 (2007)

27. Zhao, X., Xu, Y. E., Wang, J., and Yang, Z., "Analysis on the characteristics of transportation system between China and America based on the input-output theory," Proceedings of the Eastern Asia Society for Transportation Studies, Vol. 6, pp. 20-30 (2007). 